\title{
Sergey Tolstoy and The Doukhobors: The Halifax Quarantine
}

I went deep into the woods on the island along a frozen path, among the fir trees. The firs are not the same here as in Russia. The ground was covered with light snow, it was quiet, there was no one to be seen or heard, the night sky was clear. For the first time after two hectic months in a crowd I was alone with nature; for the first time after a month at sea I was on dry land; for the first time I was walking on the shore of the New World. I felt a strong emotional sense, but one difficult to put into words. I also felt a sense of relief after the voyage, as well as concern for the future, and an awareness of being separated from my customary living conditions and people close to me. ${ }^{1}$ Count Sergey Tolstoy, 1899, on first setting foot in Canada

\section{Jan. 3, 1899}

The S.S. Lake Superior leaves the Black Sea Russian port of Batoum carrying I998 Doukhobor immigrants on a 6ooomile voyage to Canada. In charge of the venture is Count Sergey Tolstoy, the eldest son of the Russian writer Leo Tolstoy.

\section{Jan. 27, 1899}

The ship arrives in Halifax Harbour and hoists the yellow quarantine flag from its mainmast, a signal that a quarantine inspection is required. Ten days earlier a six-year-old child from the Sukhachev family had presented with a high temperature and rash. Sergey Tolstoy had heard that it was measles and described the little girl as being in an excited state and chattering on without stopping. The ship's doc- tors diagnose smallpox and off she goes along with her family into isolation. Her symptoms progressively worsen and she dies on Jan. 23, 4 days before the ship is to arrive in Halifax. The incubation period for smallpox is fourteen days. This means that the passengers, crew and materials on board the ship are potentially infectious. Sergey Tolstoy describes the events that followed in his diary:

First of all the quarantine boat approaches, and our doctor calls out: "One case of smallpox! other boats approach but immediately turn back; all others are sent away, and two doctors come on board with expressionless, clean shaven faces, and we sail into quarantine. The quarantine site is on the uninhabited Lawlor's Island, roughly six miles from Halifax. It turns out that a case of smallpox means three weeks detainment in quarantine. Everyone is very alarmed; they keep asking me, but I myself know nothing. The captain and his crew are not in a good mood, nothing is being done as it should. Finally we put in to a wooden dock on Lawlor's Island, but the doctors will not let anyone ashore, and it is only from the ship that we see the low-lying shore covered by a grove of young fir-trees. It is cold, frosty and windy. The night promises to be very cold.

The cold weather is a problem but there are other more pressing problems for the port health officials. Accommodation at the quarantine station on Lawlor's Island is limited to I40o. Carpenters have been working on a new second-class detention building on the Eastern Passage side of the island, but it isn't completed. Preparations and provision of food is anticipated to be a costly major undertaking. The logistics of fumigating the ship and its contents, disinfecting the immigrants and their clothing and ensuring they are properly vaccinated is daunting enough. To accomplish all this with a group who speak a foreign language and, for over a century, have opposed any outside authority, is a formidable task.

The story of the Doukhobors' I899 winter quarantine in Halifax had its beginnings far earlier in Russian history. The Doukhobors were one of a number of sects that broke away from the Russian Orthodox Church in the 17th century. Opposed to the ritual, sacraments and the intermediary role of priests in the Orthodox church, they taught that the Spirit of God resides in everyone and that to violate a human being in any way is to defile the Spirit of God in him. The expression of this belief was pacifism and the conviction of the equality of all human beings, regardless of their station in life. Inevitably this position led to conflict with government, and over the years the Doukhobors were persecuted and exiled to the expanding frontiers of the Russian Empire.

In I895, Doukhobor communities in the Caucasus infuriated Tsarist authorities by refusing conscription and burning arms they had been issued years before to protect themselves. This act of defiance provoked brutal repression from the government.

The plight of the Doukhobors was brought to the attention of Leo Tolstoy, who admired their Christian communal agrarian lifestyle. Through his extensive network of contacts and the British and American Quakers, he organized and helped finance, in part with royalties from his novel, Resurrection, the immigration of a large group of Doukhobors to Canada, including the group on the S.S. Lake Superior. 
Anticipating a major undertaking, Dr. Frederick Montizambert, the superintendent of the Grosse Îsle quarantine station, and since 1894 the head of quarantine services for Canada, has come to Halifax to personally oversee the quarantine of the S.S. Lake Superior. He and Dr. Guy Carlton Jones, the assistant quarantine officer in Halifax, join the Doukhobors in their quarantine.

To satisfy quarantine regulations the ship and its contents have to be evacuated, sealed and fumigated with sulphur under pressure. The Doukhobors and the ship's crew must all be vaccinated against smallpox and disinfected in a bath. Their clothing had to be adequately treated, and finally, I4 days have had to have passed without any exposure to potentially infected material. However, with the inadequate accommodations on Lawlor's, not everyone can leave the ship and so the whole process was delayed.

This delay is compounded by problems with the carpenters from Halifax who are slow in completing the second-class detention building. Tolstoy thinks they are dragging their feet because they are being paid \$1.50 a day (3 roubles) - an excellent wage. The carpenters leave the island during the quarantine, and the building is finished by the Doukhobors.

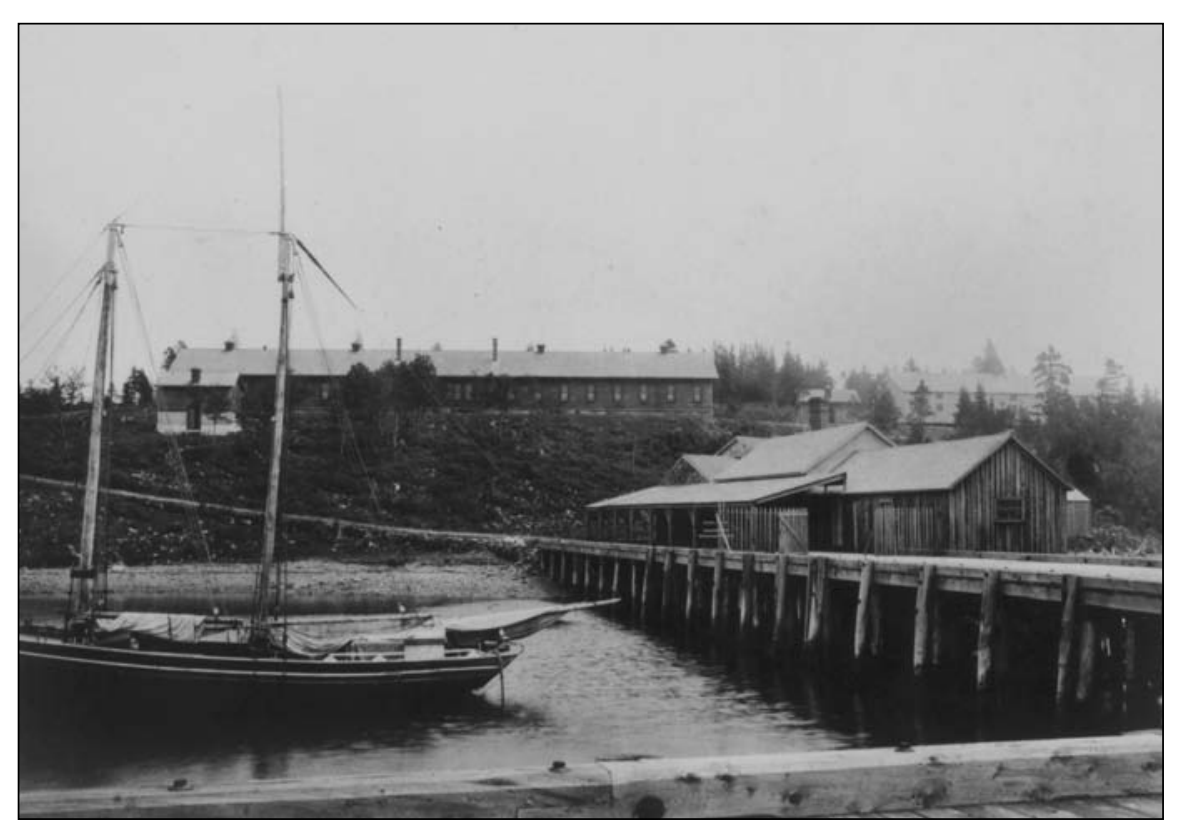

This image shows the main deep water wharf where the Doukhobors would have arrived.

Communication is also a problem, as Sergey Tolstoy is the only person who can speak both English and Russian. This situation is improved when Joseph Burnstein joins the quarantine as an additional interpreter.

The authorities are relieved to find the Doukhobors are vegetarians and have a supply of food, which Sergey Tolstoy replenishes using communal funds. The Doukhobors are eagerly awaiting the arrival of cabbage. Tolstoy records that "everybody is dreaming about cabbage." Unfortunately, that is the one vegetable Tolstoy forgets to order. DeWolf \& Son must have sent cabbage in the next order there is no further mention of cabbage dreams. Eventually the Doukhobors take over their own cooking, mainly in the ample kitchen in the third-class detention building, where they use iron griddles to bake their tasty churek - a bread Tolstoy describes as being made from the "splendid" Doukhobor wheat flour. The men are given permission to cut firewood and begin whittling wooden spoons. To the amazement of the people in Halifax the Doukhobor ladies begin doing their laundry in subzero temperatures in Halifax Harbour. This is probably due in part to the fact that water on the island is at a premium. There are no natural springs on the island, and the well water has been exhausted after only six days. For the rest of the quarantine fresh water is brought to the island by boat and pumped into the dry wells.

Despite the cold weather and other inconveniences good things began to happen on the island. On Feb. 4 a baby boy was born to the Bondarev family not only the first recorded baby born on the quarantine station but also the first Canadian-born Doukhobor. Tolstoy records in his diary that a committee of women from Halifax sent out several barrels of apples, a box of sweets, Christmas cards and copies of Chatterbox, a children's magazine. This gesture makes the Doukhobors feel welcome as settlers, and as they feel more at home on the island, they begin plying Tolstoy with all sorts of questions about Canada: What is the soil like? How does the government work? Tell us about the Canadian people. They want to get books to learn English, and two of them, Savelij Khidjakov and Fedor Podovil'nikov, who have learned English numbers, begin jotting down English words.

\section{Sunday Feb. 5, 1899}

It was bright and sunny. The Doukhobors get washed up, put on their best clothes and hold a service on the deepwater wharf, where they sing psalms, bow and embrace one another. Tolstoy records that the English look on in amazement but with a certain respect.

Everything is not completely cozy. There are some crisp exchanges between Tolstoy and Drs. Montizambert and Jones when the last Doukhobors are ordered out of the comparatively warm ship, so that it can be fumigated, and moved into the new second-class dormitory. Here it is so cold that wet shirts hung up the previous night become stiff with frost. When the fumigation process is delayed the doctors won't allow the Doukhobors back on the ship. A truce is reached when Dr. Montizambert comes up with additional stoves and insulation for the new building.

The fumigation delay is bureaucratic. The engineer responsible re- 


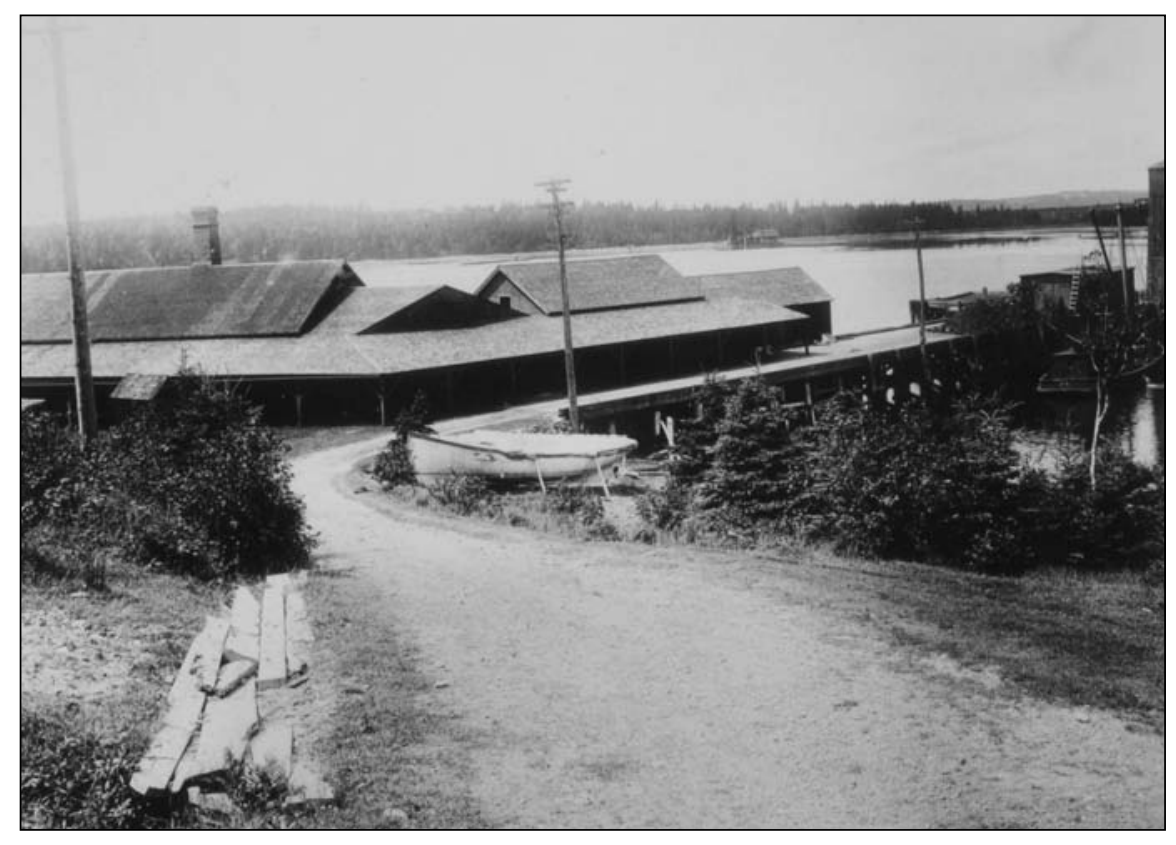

A view of the bath house from the island side.

fuses to begin the process until he has clearance from his superiors in Customs. Ottawa grants permission, and the fumigation of the ship proceeds.

Once the Doukhobors have all been vaccinated the process of bathing and disinfecting clothing begins. Groups of 60 are brought to the bathhouse where they are bathed in steam-heated water with a disinfectant solution. While they are bathing, their clothing is exposed to dry heat to a temperature of $180^{\circ} \mathrm{F}$, followed by steam heating to a much higher temperature. Then the clothing is rapidly dried and returned. Complete drying is difficult to achieve, and so there are some frosty trips back to the quarantine buildings.

Despite this health peril, there is only one case of pneumonia.

The sheepskin coats would not fare well with the steam treatment and so they are specially treated with formaldehyde.

On February 17 the quarantine regulations have been fulfilled. There are no cases of smallpox. Before allowing passengers and crew to reboard the S.S. Lake Superior, Dr. Montizambert requires them to present a red ticket if they have been vaccinated and it has taken. A white ticket indicates the first vaccination has not taken and they have been re-vaccinated, and a yellow ticket indicates the disinfection process has been completed. Tolstoy records that the labelling of disinfected luggage did cause problems. The label attached to the luggage displays a red cross, the Canadian coat of arms and the word "disinfected." The Doukhobors object to the red cross. The cross, to them, is the instrument of Christ's execution and they don't want it on their property. Sergey Tolstoy records that:

Dr. Jones was irritated and began saying that the Doukhobors look as if they want to run the country, that they don't obey the quarantine laws very well, etc. Dr. Montizambert, who is much milder than Jones, said with a condescending smile only that the quarantine regulations must be heeded, that the sign of the red cross is used throughout the world, and that he was not able to grant the Doukhobors' request.

Some of the Doukhobors attempt to scrape off the cross, but the majority ignore it.

\section{Afternoon Feb. 17, 1899}

The Doukhobors leave Halifax Harbour singing psalms at the ships rails, bound for Saint John and their new homes in Western Canada.

Sergey Tolstoy recorded many wonderful and insightful impressions of his time in quarantine. Toward the end of the quarantine he gives a description of what happens to rats after the ship had been fumigated with sulphur dioxide.

Yesterday and today they fumigated the whole ship with sulphur dioxide, except for the firstclass cabins, for which they used formalin. This evening, around ten o'clock, I was sitting alone in the ship's dining-room, writing letters and reading newspapers. Almost always around this time the ship's rats begin scratching and scurrying about; occasionally one of them darts across the floor; today, however, with the fumigation, they all gathered at the stern and raised a real ruckus; first one darted past, then two, then several, and then a whole lot of them began scurrying all over the dining-room and even jumping up to the table where I was writing. I fearfully gathered up my papers and fled to my cabin.

Just prior to the S.S. Lake Superior's departure for Saint John, Sergey Tolstoy went into Halifax to settle the Doukhobors' accounts. Here is what he said:

Halifax, at least in its outward appearance, is nothing out of the ordinary. There are a lot of pot-holes on the streets; the snow is hardly cleared away at all; I saw several large double sleighs outfitted with buffalo rugs. People wear knitted caps in the shape of a stocking and fur coats with fur on the outside.

He wrote his oldest sister Tanja about his time on Lawlor's Island. Aside from the sea and the biting winds he says the landscape is very Russian - like Moscow Province. Then he says:

The experiments conducted by the autocrat Dr. Montizambert and his Grand Vizier Dr. Jones are coming to an end. They have (I) inoculated everyone against smallpox, (2) checked the inoculations, (3) dry-cleaned underwear and clothing, (4) fumigated the sheepskin coats; (5) been washing everyone in a bathhouse. Everyone is healthy, more or less ... the journey is almost over.

Sergey Tolstoy stayed with the Doukhobors through the rest of the winter until they were well launched in their new homeland. At the end of March he returned to Russia via Toronto, Montreal and New York.

\section{Ian Cameron}

Family Medicine

Dalhousie University

Halifax, NS

\section{REFERENCE}

I. Tolstoy S. Sergej Tolstoy and the Doukhobors: a journey to Canada, Slavic Research Group. Ottawa: University of Ottawa; 1998. 